\title{
Flexural Behaviour of Self Compacting Concrete Beam using Welded Wire Mesh as Shear Reinforcement
}

\author{
Nithin K R ${ }^{1}$, N Saravana Kumar ${ }^{2}$ \\ ${ }^{1}$ PG Student, Civil Engineering Department, Mepco Schlenk Engineering College, Sivakasi, TamilNadu, India \\ ${ }^{2}$ Assistant Professor, Civil Engineering Department, Mepco Schlenk Engineering College, Sivakasi, TamilNadu, India
}

\begin{abstract}
Conventional shear reinforcement cannot provide superior shear characteristics for concrete beam due to the problems in detailing and the disturbance caused to the concrete continuity. This paper is an effort to tackle that problem by the usage of welded wire reinforcement as shear reinforcement along with the vertical stirrups. A total of six specimens were cast and the volumetric ratios of the stirrups and the welded wire mesh are varied in each specimen. The mesh used was commonly available galvanized welded wire mesh of opening $1 / 2$ inch $x 1 / 2$ inch. Since the mesh size is very small and to ensure strength and homogeneity self compacting concrete was used. Its wide spread usage was also considered. The result indicates improved strength characteristics using the mesh layer in addition to the stirrups. There were also improvements in maximum deflection and ductility of the beam.
\end{abstract}

Keywords: Welded wire mess, Shear reinforcement, Stirrups, Self Compacting Concrete

\section{Introduction}

The experimental study carried out under this paper is the flexural behavior of an RC beam using Welded Wire Mesh (WMM) as shear reinforcement. This welded wire mesh is formed from stainless steel which has high strength, flexibility and corrosion resistance. It is advantageous due to ease of availability, lower cost as well as better quality control. The volumetric ratio of stirrups reduces the shear characteristics of concrete core, high volumetric ratio of stirrups affects the continuity of concrete and leads to a plane of weakness between the core and the concrete cover. Welded wire mesh can be used as a substitute for the conventional reinforcement and will yield excellent results both in flexural as well as shear capacity. But the structural behavior of RC beams with welded wire mesh as shear reinforcement is little known. The significance of this study lies in this context. This study is done using six specimens. Out of them five specimens are wound with welded wire mesh and the number of stirrups and mesh layers vary in each case, while the other specimen is with conventional reinforcement used as control specimen. The parameters which are investigated in this study includes the ultimate load capacity, maximum deflection, pattern of cracks, ductility. The results indicate that the strength, of concrete beam is comparable with that of the control specimen with single layer of mesh and shows significant improvement if the numbers of mesh layers are increased to two.

\section{Experimental Program}

The experimental investigation is conducted as discussed below. All the material tests were conducted in the laboratory as per relevant Indian Standard codes. Basic tests were conducted on fine aggregate, coarse aggregate, and cement to check their suitability for concrete preparation. The study aims to investigate the strength related properties of concrete of M40 grade. The proportions of ingredients of the concrete of grade M40 had to be determined by mix design as per guidelines given for self compacting concrete design. Totally three cube specimens, three cylinders were cast for M40 grade of concrete in this study. Five of the beams were with welded mesh with varying stirrups and varying mesh layers. The parameter to be investigated in this study included the spacing and grid configuration of Weld Wire Mesh and the shear reinforcement. Six beam specimens of size $150 \mathrm{~mm}$ x $150 \mathrm{~mm} \times 1100 \mathrm{~mm}$ were cast, cured.

An experimental investigation of the specimens is conducted as shown below. Initially all the materials tests were conducted in the laboratory as per their respective Indian Standard Codes. The preliminary tests were conducted on fine aggregate, coarse aggregate and cement to check their suitability for making self compacting concrete. After the preliminary tests the compressive strength of the mix design (Nan-su-et.al method) of self compacting concrete (M 40 grade) was verified. After testing the compressive strength the fresh concrete were performed for SCC and the mix was found to be satisfying. Total of six specimens were cast with different volumetric ratio of stirrups and different number of mesh layers. They were cured for 28 days and tested under two point loading and checked for flexural capacity and other salient properties.

Table 1: Details of beam specimens tested

\begin{tabular}{|c|c|c|c|c|c|c|}
\hline \multirow{2}{*}{$\begin{array}{c}\text { Specimen } \\
\text { name }\end{array}$} & \multirow{2}{*}{$\begin{array}{l}\text { Cross } \\
\text { section } \\
\text { details } \\
(\mathrm{mm})\end{array}$} & \multirow{2}{*}{$\begin{array}{c}\text { Length } \\
(\mathrm{mm})\end{array}$} & \multirow{2}{*}{$\begin{array}{c}\text { Main } \\
\text { reinforc- } \\
\text { ement }\end{array}$} & \multicolumn{2}{|c|}{ Stirrups } & \multirow{2}{*}{$\begin{array}{c}\text { No. } \\
\text { of } \\
\text { WWM } \\
\text { layer }\end{array}$} \\
\hline & & & & No. & Spacing & \\
\hline SICS & $150 \times 150$ & 1100 & $4 \# 10 \mathrm{~mm}$ & $7 \# 8 \mathrm{~mm}$ & $175 \mathrm{~mm}$ & nil \\
\hline S2SL & $150 \times 150$ & 1100 & $4 \# 10 \mathrm{~mm}$ & $7 \# 8 \mathrm{~mm}$ & $175 \mathrm{~mm}$ & 1 \\
\hline S3SL & $150 \times 150$ & 1100 & 4\#10 mm & $5 \# 8 \mathrm{~mm}$ & $262 \mathrm{~mm}$ & 1 \\
\hline S4SL & $150 \times 150$ & 1100 & $4 \# 10 \mathrm{~mm}$ & $3 \# 8 \mathrm{~mm}$ & $525 \mathrm{~mm}$ & 1 \\
\hline S5DL & $150 \times 150$ & 1100 & $4 \# 10 \mathrm{~mm}$ & $5 \# 8 \mathrm{~mm}$ & $262 \mathrm{~mm}$ & 2 \\
\hline S6DL & $150 \times 150$ & 1100 & 4\#10 mm & $3 \# 8 \mathrm{~mm}$ & $525 \mathrm{~mm}$ & 2 \\
\hline
\end{tabular}




\section{International Journal of Science and Research (IJSR) \\ ISSN (Online): 2319-7064}

Index Copernicus Value (2013): 6.14 | Impact Factor (2015): 6.391

\subsection{Material Properties}

The cement used is commercially available Portland pozzolona cement (PPC) conforming to IS: 8112-1989, with a specific Gravity 3.13

Fine aggregate is locally available river sand of size below $4.75 \mathrm{~mm}$ with specific gravity 2.5 conforming to Zone II of IS 383-1970 is used as fine aggregate. The physical properties as per IS 2386 (Part III) were also found using laboratory experiments. The Fineness modulus is 2.89 and Bulk density $1629.74 \mathrm{Kg} / \mathrm{m}^{3}$ as per these experiments.

Coarse aggregate used in this study consists of maximum size $12.5 \mathrm{~mm}$ and minimum size of $10 \mathrm{~mm}$. The physical properties as per IS 383-1970 were also found using laboratory experiments. The Specific gravity is 2.65 and Bulk density is $1547.58 \mathrm{Kg} / \mathrm{m}^{3}$ as per these experiments.

HYSD bars of $10 \mathrm{~mm}$ and $8 \mathrm{~mm}$ were used as longitudinal reinforcement and lateral ties respectively. Typical EMM sheets of size $1 \mathrm{~m} \times 10 \mathrm{~m}$ weighting $13 \mathrm{~kg}$ per sheet were used. The mesh has square shaped opening with size $1 / 2$ inch $\mathrm{x} 1 / 2$ inch and strand diameter $1.25 \mathrm{~mm}$.

Silica fume of specific gravity 2.1 as cement replacement and super plasticizer Glenium b 233 was used with a dosage of $1.4 \%$ (dosage found using marsh cone test ) of cement content.

\subsection{Preparation of the specimens}

The beam specimens are prepared according to the following procedure

\subsubsection{Reinforcement}

Four bars of $10 \mathrm{~mm}$ diameter were as the longitudinal reinforcement. Each of the beam specimens has distinguished lateral reinforcement as given in Table 1 and shown in Fig 1. The welded wire mesh was connected to the beam specimen by using steel winding wires. The cover of the specimen was maintained at $25 \mathrm{~mm}$.

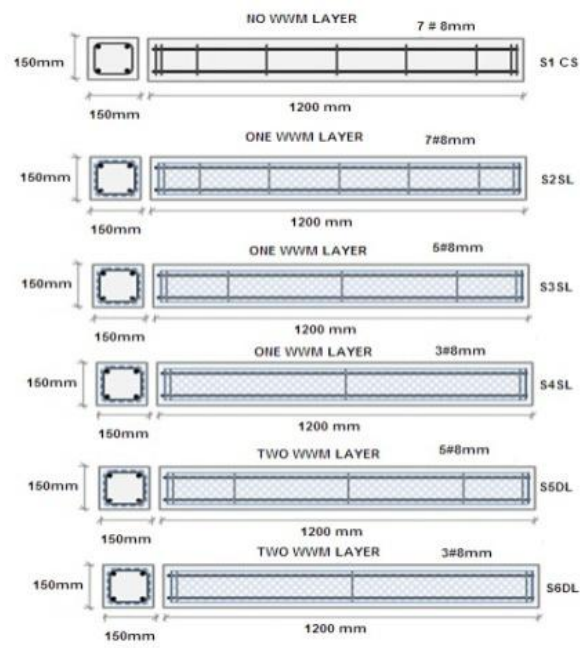

Figure 1: Dimensions and reinforcement details of tested beam specimens

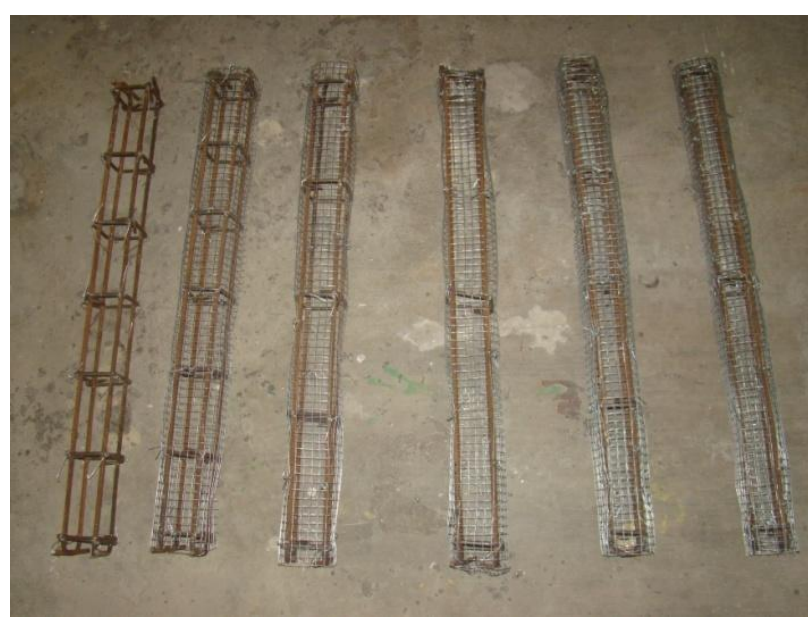

Figure 2: Reinforcement of beam specimens

\subsubsection{Mixing and casting of the beam specimen}

The mixing of the specimen was done after doing the fresh tests for SCC. The mix design for self compacting concrete was done by using the Nan-su- et.al method and the cube compressive strength obtained for a design mix of $1: 2.28$ : 1.85: 0.34 was $46.2 \mathrm{KN} / \mathrm{mm}^{2}$. The values corresponding to fresh concrete tests are $0.85,1,8 \mathrm{sec}, 710 \mathrm{~mm}$ for $\mathrm{L}$ box, $\mathrm{U}$ box, V funnel, slump flow tests respectively. All this values are within permissible limits.

The mixing of the concrete was done in an electronic drum mixture machine and poured with self compacting mixture machine manually. The specimens were unmoulded after 24 hours and cured in a water tank for 28 days. After curing they were kept for drying and coated with lime for visibility of cracks during testing.

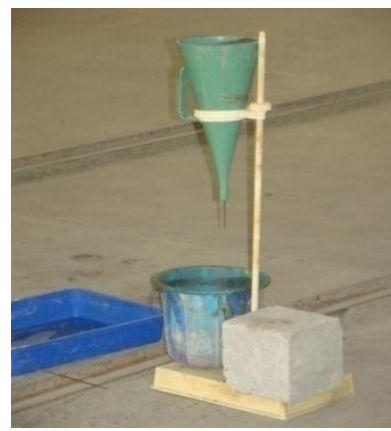

Figure 3: Marsh cone test for finding super plasticizer dosage

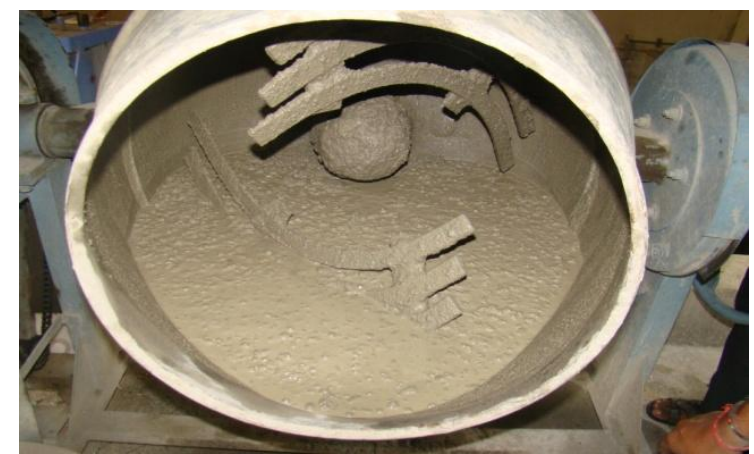

Figure 4: Self compacting concrete mix in the electronic drum mixture

Volume 5 Issue 6, June 2016 www.ijsr.net

Licensed Under Creative Commons Attribution CC BY 


\section{International Journal of Science and Research (IJSR) \\ ISSN (Online): 2319-7064}

Index Copernicus Value (2013): 6.14 | Impact Factor (2015): 6.391

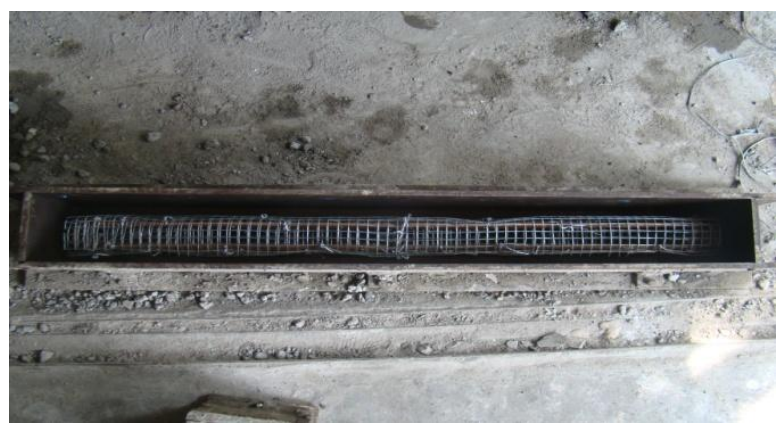

Figure 5: The casting mould and the reinforcement of the specimen

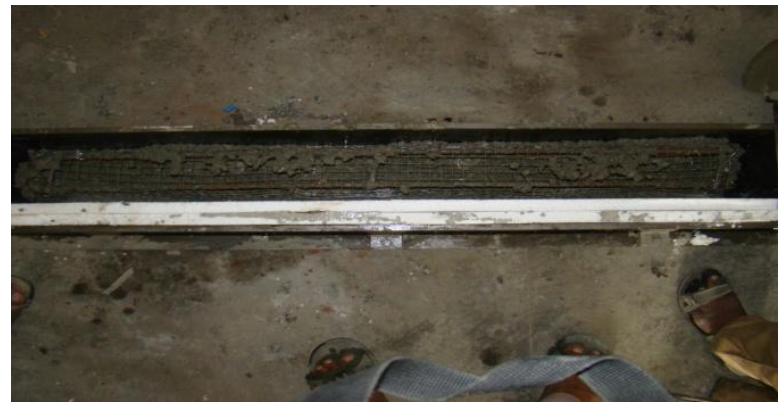

Figure 6: The specimen during casting

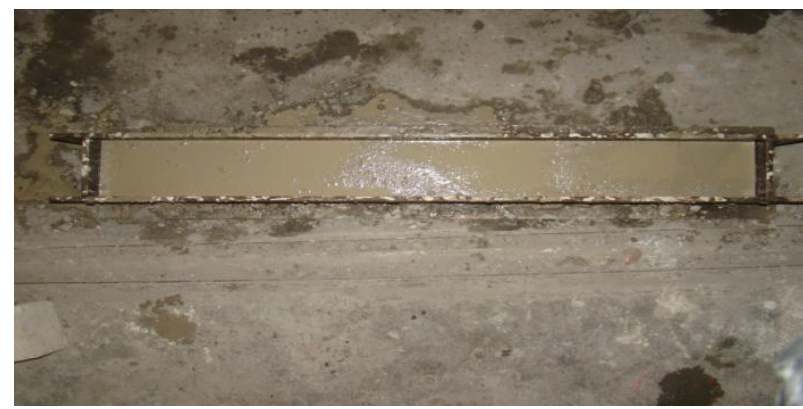

Figure 7: The specimen after casting

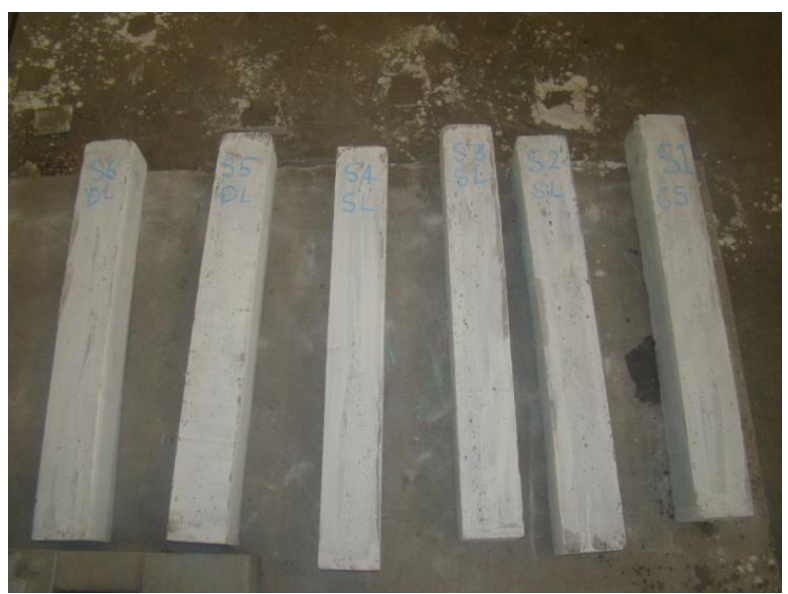

Figure 8: The specimen ready for testing

\subsubsection{Instrumentation and test setup}

The instrumentation and test setup are shown in fig 9. Tests were conducted using hydraulic loading machine mounted on a testing frame of $500 \mathrm{kN}$ capacity. All the specimens were kept at a span length of $1000 \mathrm{~mm}$ (L) and were subjected to two point loading. The deflections at the middle, $L / 3$ and $2 \mathrm{~L} / 3$ of the span were measured using dial gauges.

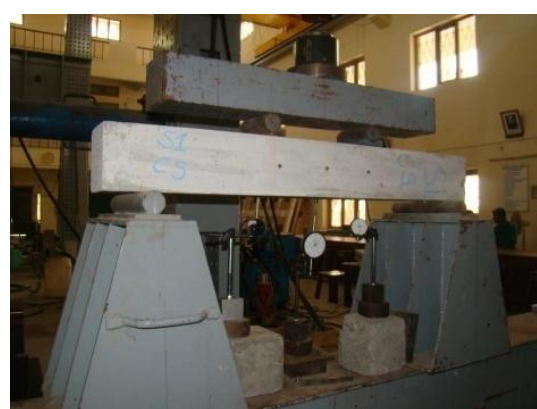

Figure 9: The test setup of the specimen

\section{Experimental Results and Discussion}

Table 2 gives the ultimate load and the maximum deflection. The figure 10-15 shows the load-deflection curves for the specimens given in Fig 1.

\subsection{Ultimate Load}

The experimental results suggest that the ultimate load capacity of the beam specimens is increased only marginally for the S2SL specimen with the increase of one layer of welded wire mesh. But with increasing mesh spacing in S3SL and S4SL the ultimate load capacity is found to be decreased by $19.3 \%$ and $20.9 \%$ respectively. This indicates that the single layer mesh used will not increase the strength of the beam specimen when the spacing of the stirrups is increased. Further study using thicker meshes are recommended. When double layers of Welded Wire Mesh are used the strength of the specimen with 5 numbers of stirrups (S5DL) is $126 \%$ of the control specimen and the specimen with 3 numbers of stirrups (S6DL) is $98 \%$ of the control specimen. Therefore, the beam with double layer of mesh of the size used in this study can be used as an alternative to control specimen using more number of stirrups. The alternatives proposed for the S1CS is are S5DL and S6DL.

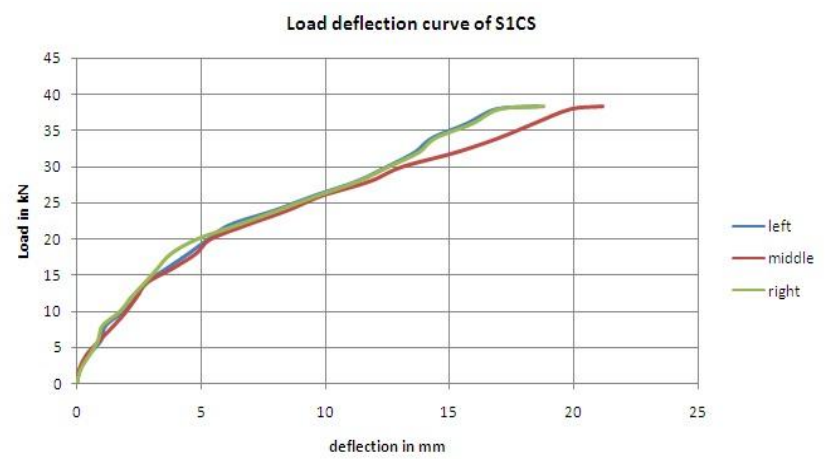

Figure 10: Load deflection curve of S1CS

Volume 5 Issue 6, June 2016 www.ijsr.net 


\section{International Journal of Science and Research (IJSR) \\ ISSN (Online): 2319-7064}

Index Copernicus Value (2013): 6.14 | Impact Factor (2015): 6.391

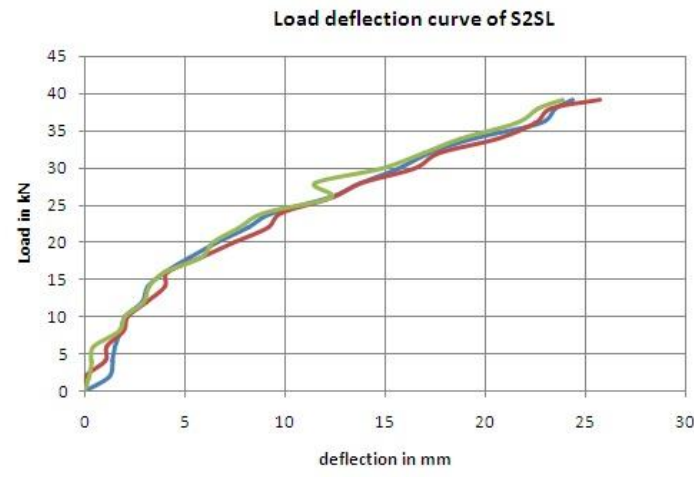

Figure 11: Load deflection curve of S2SL

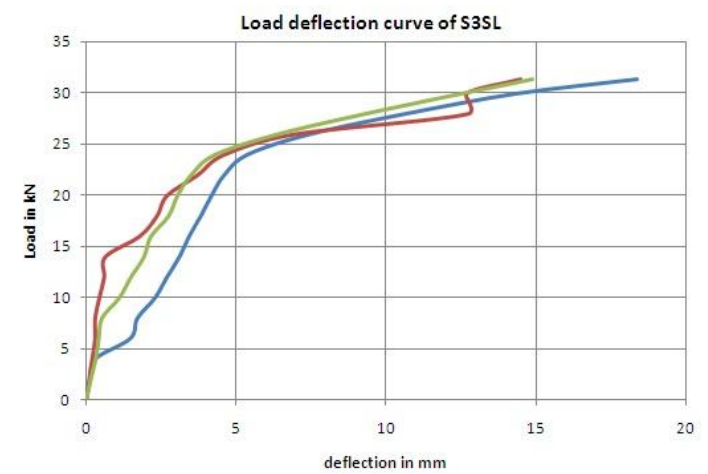

Figure 12: Load deflection curve of S3SL Load deflection curve of S4SL

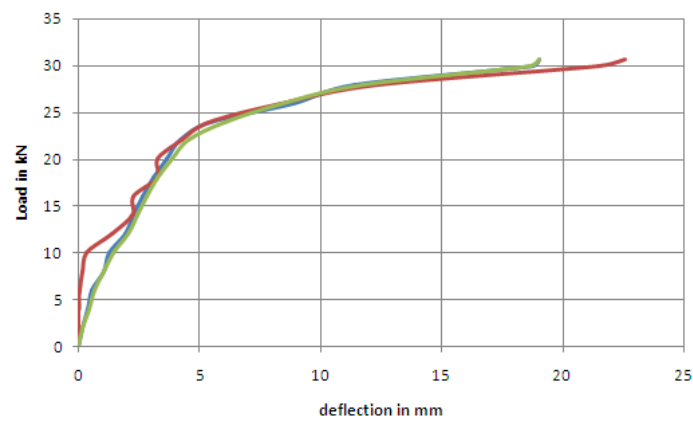

Figure 13: Load deflection curve of S4SL

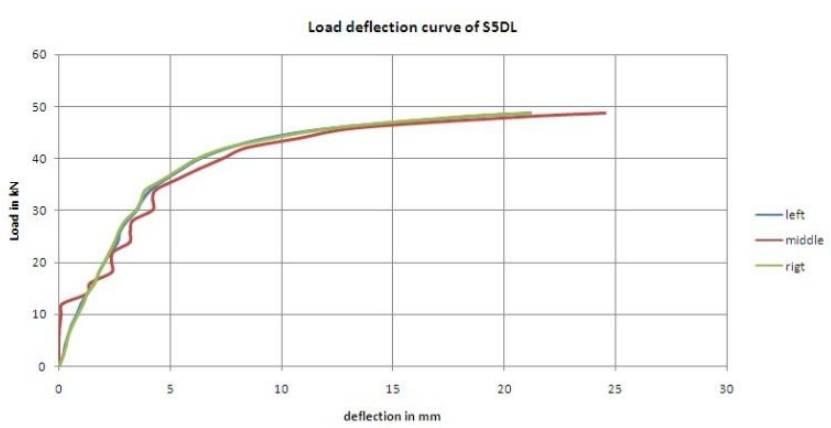

Figure 14: Load deflection curve of S5DL

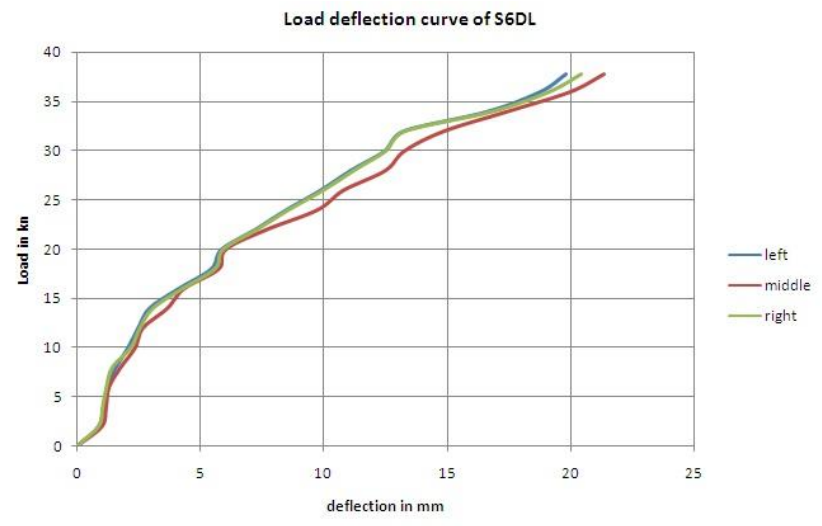

Figure 15: Load deflection curve of S6DL

\subsection{Maximum Deflection}

The maximum deflection values of the specimens increased is increased in specimen S2SL with addition of one layer of WWM. The deflection value decreases for the S3SL specimen whereas unlike expectation the maximum value of S4SL specimen is comparable with that of the control specimen, S1CS. Also there is no remarkable increase in the maximum deflection value by providing double layer of welded wire mesh. Even though with lesser number of stirrups and a double layer we are able to achieve marginally higher maximum deflection value.

The experimental results for the specimens are shown in the Table 2

Table 2:- Test results of the beam specimens

\begin{tabular}{|c|c|c|c|c|c|}
\hline $\begin{array}{c}\text { Specimen } \\
\text { name }\end{array}$ & $\begin{array}{c}\text { Number } \\
\text { of } \\
\text { WWM } \\
\text { layer }\end{array}$ & $\begin{array}{c}\text { Number } \\
\text { of } \\
\text { stirrups }\end{array}$ & $\begin{array}{c}\text { First } \\
\text { cracking } \\
\text { load in } \\
\text { KN }\end{array}$ & $\begin{array}{c}\text { Ultimate } \\
\text { load in } \\
\mathrm{kN}\end{array}$ & $\begin{array}{c}\text { Maximum } \\
\text { deflection }\end{array}$ \\
\hline S1CS & nil & 7 & 12 & 38.4 & 21.17 \\
\hline S2SL & 1 & 7 & 14 & 39.1 & 25.7 \\
\hline S3SL & 1 & 5 & 14 & 31.4 & 18.37 \\
\hline S4SL & 1 & 3 & 14 & 30.7 & 21.47 \\
\hline S5DL & 2 & 5 & 22 & 48.7 & 21.18 \\
\hline S6DL & 2 & 3 & 16 & 37.8 & 21.35 \\
\hline
\end{tabular}

\subsection{Ductility}

The load deflection curves show that the ductility of the specimen increases with addition of single layer of WWM on the control specimen which can be observed in S2SL specimen. The decrease in number of stirrups does not affect the ductility significantly. Also by reducing the number of stirrups and increasing the number of layers the ductility of the specimen can be made marginally more than the control specimen.

\subsection{Cracks}

The cracks developed in each specimen are shown in the figures below. It can be observed that the cracks in the control specimen are mainly flexural and the specimens with single layer of mesh also mainly flexural. But when we use the double layer of mesh the cracks are both flexural as well as shear failure. 


\title{
International Journal of Science and Research (IJSR) \\ ISSN (Online): 2319-7064
}

Index Copernicus Value (2013): 6.14 | Impact Factor (2015): 6.391

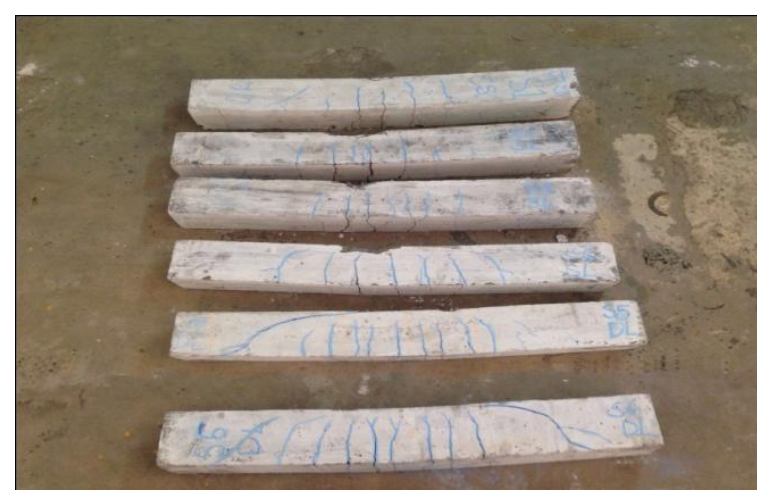

Figure 16: The specimens after the test

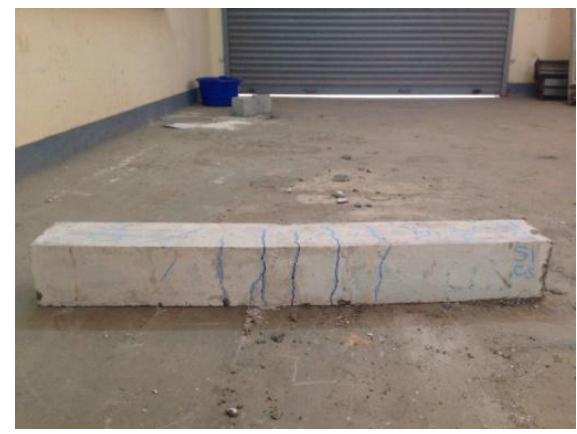

Figure 17: Crack pattern of S1CS specimen

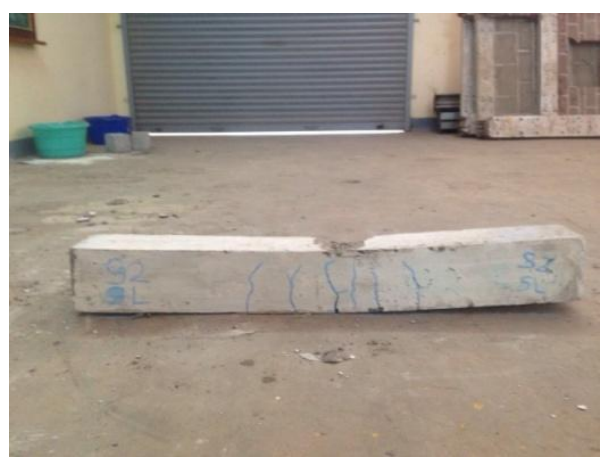

Figure 18: Crack pattern of S2SL specimen

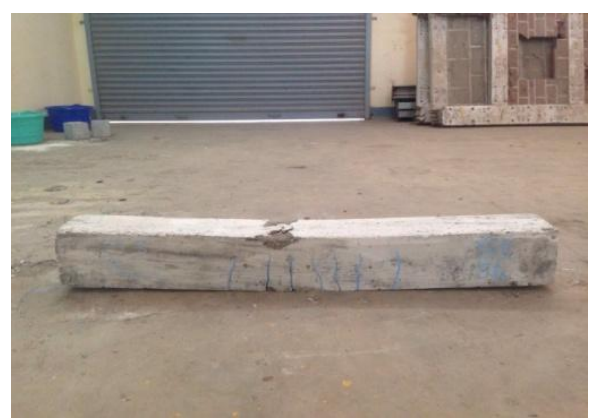

Figure 19: Crack pattern of S3SL specimen

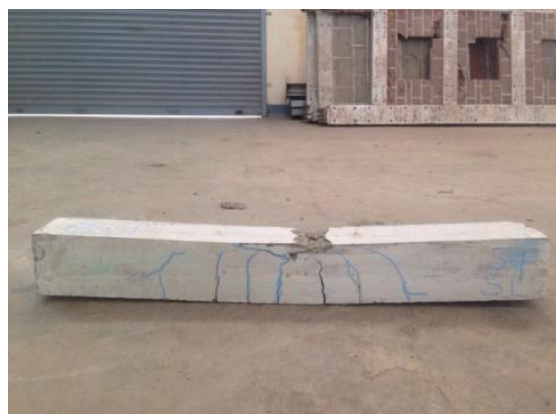

Figure 20: Crack pattern of S4SL specimen

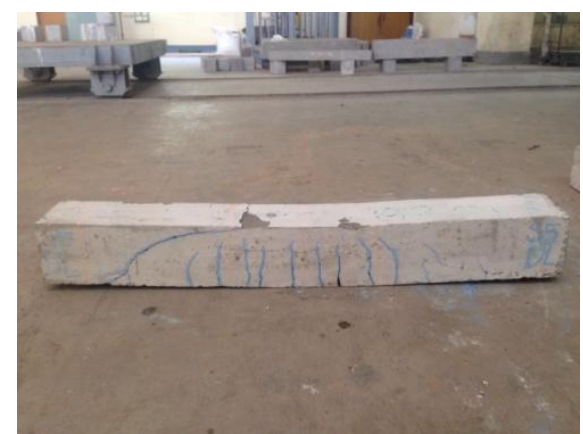

Figure 21: Crack pattern of S5DL specimen

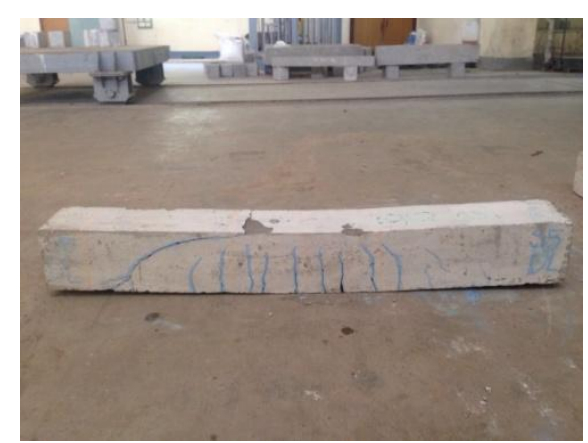

Figure 21: Crack pattern of S6DL specimen

\section{Conclusions}

The conclusions of this paper are presented by investigating varying spacing and number of WWM layers of a control beam specimen. The inferences are

1) The ultimate load of the beam specimen increases marginally by adding one layer of Welded Wire Mesh. With increase in spacing it decreases by $19.3 \%$ and 20.9 $\%$ for the S2SL and S3SL specimens.

2) By increasing the number of mesh layer to two we obtain $126 \%$ and $98 \%$ of the ultimate load for specimens S5DL and S6DL.

3) The maximum deflection increases considerably with adding one layer on the control specimen

4) The maximum deflection increases marginally for the specimens with higher spacing of stirrup for both single and double mesh layers.

5) The ductility of the specimens increases for the specimen S2SL considerably compared to the control specimen S1CS and comparable with all other specimens.

6) The crack pattern is flexural mainly for the specimens S1CS, S2SL, S3SL. It is a combination of flexural and shear for S4SL. The predominant cracks observed in S5DL and S6DL are shear cracks originating from the support to the point of loading.

\section{References}

[1] Ahmed M. El-Kholy and Hany A. Dahish, -Improved confinement of reinforced concreteColumnsll, Elvesier, Al Shams Engineering Journal (2015)1-10

[2] P. Dinakar, Kali Prasanna Sethy, Umesh C. Sahoo, -Design of selfcompacting concrete with ground granulated blast furnace slag,\| Sciencedirect, Materials and Design 43 (2013) 161-169

[3] P.L. Domone, - Self-compacting concrete: An analysis of 11 years of case studies,\| Elsevier, Cement \& Concrete Composites 28 (2006) 197-208

\section{Volume 5 Issue 6, June 2016}

\author{
www.jisr.net
}

Licensed Under Creative Commons Attribution CC BY 


\section{International Journal of Science and Research (IJSR) \\ ISSN (Online): 2319-7064}

Index Copernicus Value (2013): 6.14 | Impact Factor (2015): 6.391

[4] Sema Noyan Alacalı, Bulent Akbas, Bilge Dorana, Prediction of lateral confinement coefficient in reinforced concrete columns using neural network simulation,\| Elvesier, Applied Soft Computing 11 (2011) 2645-2655

[5] P.L. Domone, $-\mathrm{A}$ review of the hardened mechanical properties of selfcompacting concrete,\| Elsevier, Cement \& Concrete Composites 29 (2007) 1-12

[6] X. Xuan and S.H. Rizkalla, behaviour of welded wire fabric as shear reinforcement under cyclic loading conditions\|

[7] J.C.M. Ho, J.Y.K. Lam, A.K.H. Kwan, -Effectiveness of adding confinement for ductility improvement of high-strength concrete columns,\| Elvesier, Engineering Structures 32 (2010) 714_725

[8] Fa-xing Ding, Changjing Fang, Yu Bai, Yong-zhi Gong, Mechanical performance of stirrup-confined concretefilled steel tubular stub columns under axial loading,\| Journal of Constructional Steel Research 98 (2014) $146-157$

[9] G. Rodriguez de Sensale1; I. Rodriguez Viacava; and A. Aguado, - Simple and Rational Methodology for the Formulation of Self-Compacting Concrete Mixes,\| ASCE, Journal of Materials in Civil. Eng

[10] Ha Thanh Le, Matthias Muller, Karsten Siewert, HorstMichael Ludwig, The mix design for self-compacting high performance concrete containing various mineral admixtures, $\|$ Journal of Materials and Design 72 (2015) $51-62$

[11] Sheikh SA. Effectiveness of rectangular ties as confinement steel in reinforced concrete columns. $\mathrm{PhD}$ dissertation, Department of Civil Engineering, University of Toronto, Canada; 1978.

[12] Mourad SM, Shannag MJ. Repair and strengthening of reinforced concrete square Columns using ferrocement jackets. Cem Concr Compos 2012;34(2):288-94.

[13] Kumar PR, Oshima T, Mikami S. Ferrocement confinement of plain and reinforced concrete. Prog Struct Eng Mater 2004;6(4):241-51.

[14] Saatcioglu M, Grira M. Confinement of reinforced concrete columns with welded reinforcement girds. ACI Struct J 1999;96(1):29-39.

[15] K. Ozawa, K. Maekawa, M. Kunishima, H. Okamura, Performance of concrete based on the durability design of concrete structures, Proc. Of the Second East AsiaPacific Conference on Structural Engineering and Construction, 1989.

[16]P.K. Mehta, Concrete Structure, Properties and Materials, Prentice- Hall, 1986, pp. 367-378.

[17] A.M. Neville, Properties of Concrete, 4th ed., Longman Group, 1995, pp. 757-758.

[18] K.H. Khayat, Z. Guizani, Use of viscosity-modifying admixture to enhance stability of fluid concrete, ACI Mater. J. 94 (4) (1997) 332- 341.

[19]A. Yahia, M. Tanimura, A. Shimabukuro, Y. Shimoyama, Effect of rheological parameters on self compactability of concrete containing various mineral admixtures, in: A. Skarendahl, O. Petersson (Eds.), Proceedings of the First RILEM International Symposium on Self- Compacting Concrete, Stockholm, September, 1999, pp. 523 \pm 535 .

[20] M. Kurita, T. Nomura, Highly-flowable steel fiberreinforced concrete containing fly ash, in: V.M.
Malhotra (Ed.), Am. Concr. Inst. SP 178 (1998) 159175 (June)

\section{Author Profile}

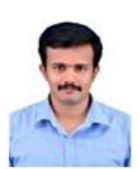

Mr. Nithin K R, currently pursuing Structural engineering post graduation at Mepco Schlenk college of Engineering, Sivakasi. His research interests are RC design, Structural analysis, earthquake analysis and non conventional materials in construction.

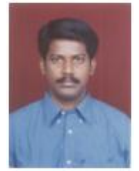

Mr. N Saravana Kumar, an Assistant Professor at Department of Civil Engineering, Mepco Schlenk college of Engineering, Sivakasi. His area of specialization encrusts Design of RC structures, Structural Analysis and Design. He has published 4 papers in International journal and took part in 12 international and 21 national conferences. He has organized one International, 4 National and 14 State level courses and participated in 5 National and 8 State level courses 